\title{
RED SQUIRREL PREDATION ON WARBLING VIREO AND YELLOW WARBLER NESTS
}

TODD J. UNDERWOOD, Department of Zoology, University of Manitoba, Winnipeg, MB R3T2N2 E-mail: umunderw@cc.umanitoba.ca

Red squirrels (Tamiasciurus hudsonicus) are well known as opportunists that depredate songbird nests and occasionally adult birds. ${ }^{6,10}$ Although eggs and nestlings are not typically considered major food items, ${ }^{10}$ predation by red squirrels is believed to be a major source of nest failure for many songbirds. ${ }^{11}$ Because predation events at songbird nests are infrequently observed ${ }^{7}$ and predator identity cannot reliably be determined from nest remains, ${ }^{4}$ anecdotal observation of predation events provides useful information regarding the identity of predators at songbird nests. Sealy reported that red squirrels were responsible for 12 of 23 songbird nest predation events observed at Delta Marsh, Manitoba between 1974 and $1994,{ }^{9}$ excluding egg destruction by species such as wrens ${ }^{2}$ and egg removal in relation to brood parasitism by Brownheaded Cowbirds. ${ }^{8}$ Here, I report three additional incidents of nest predation by red squirrels at Delta Marsh over four field seasons, 1998-2001, one on a Warbling Vireo nest and two on Yellow Warbler nests.

\section{Warbling Vireo nest}

On 22 June 1998 at 8:24 pm, the alarm calls of Warbling Vireos drew Robyn Underwood and me toward a vireo nest that I had been monitoring for several days. A red squirrel was on a branch about $0.5 \mathrm{~m}$ from the nest, which was $9 \mathrm{~m}$ high in an Eastern Cottonwood (Populus deltoides). The squirrel held a vireo nestling by the wings and was eating it despite the constant calls and dives from the pair of adult vireos. The attacks, including direct strikes on the squirrel, persisted for two and a half minutes. The squirrel then carried the nestling to an adjacent tree. The vireos continued to attack the squirrel, which was now about $5 \mathrm{~m}$ from the nest, but with less intensity than at the beginning of the event. By 8:35 pm, the vireos had stopped alarm calling and no longer attacked the squirrel. We did not observe what the squirrel ultimately did with the nestling. On 20 June, the vireo nest contained three nestlings approximately 5-6 days old. Evidently, on 22 June the squirrel removed only one nestling because the nest contained two nestlings on 23 June. However, the nest was empty on 25 June, too soon for the young to have fledged. ${ }^{3}$

\section{Yellow Warbler nests}

On 15 June 2001 at 6:50 pm, Robyn Underwood, Spencer Sealy and I observed a red squirrel with an egg in its mouth at a Yellow Warbler nest about $5 \mathrm{~m}$ high in a Manitoba Maple (Acer negundo). A Yellow Warbler was alarm calling and dove at the squirrel at least once but did not strike it. When the three of us approached the nest to better observe the event, the squirrel climbed about $3 \mathrm{~m}$ above the nest where it finished eating the egg before moving off. I do not know the final outcome of this nest.

On 29 June 2001 at 7:05 pm, the alarm calls of several Baltimore Orioles and a pair of Yellow Warblers drew my attention to a red squirrel. The squirrel with a wellfeathered nestling in its mouth was running up a tree and away from a Yellow Warbler 
nest that was $8 \mathrm{~m}$ high in an unidentified tree. The squirrel stopped above the nest and began eating the nestling, while the warblers continued to give alarm calls. At $7: 13 \mathrm{pm}$, the squirrel stopped eating the nestling and wedged what was left of it into a crotch of the tree about $2 \mathrm{~m}$ above the nest. The squirrel ran back to the nest where the adult warblers increased the intensity of their defensive response and began diving at it. I did not observe what the squirrel did at the nest, but it appeared that a nestling fell out. Immediately after this, the squirrel ran about $3 \mathrm{~m}$ down the tree and jumped over to an adjacent tree, chased by the adult warblers the entire way. The squirrel ran up the second tree and stopped at a height above that of the nest. After several minutes observing the stationary squirrel, I walked to the base of the nest tree and searched for the fallen nestling, but did not see any sign of it. I do not know the final outcome of this nest.

\section{Conclusion}

During four summers of work at Delta Marsh, these three incidents were the only nest predation events I observed. Of the seven previous observations of predation on Yellow Warbler nests at Delta Marsh, four were by red squirrels and all of these were during the egg stage. ${ }^{9}$ The two additional observations of predation on Yellow Warbler nests documented here appear to be the first of red squirrel predation on Yellow Warbler nestlings ${ }^{5}$ and provide further evidence that red squirrels are a primary predator on Yellow Warbler nests at Delta Marsh. Although red squirrels have been suspected to be predators on Warbling Vireo nests, little is known about the identity of predators on this species' nests. ${ }^{3}$ Previously, the only instance of predation on a Warbling Vireo nest observed at Delta Marsh was by a Yellowheaded Blackbird during the egg stage. ${ }^{9} \mathrm{My}$ observation is the first documentation of red squirrel predation on a Warbling Vireo nest. $^{3}$

\section{Acknowledgments}

I thank Spencer Sealy and Robyn Underwood for assistance with field observations and for commenting on this note.

1. BAYNE, E. M., and K. A. HOBSON. 2002. Effects of red squirrel (Tamiasciurus hudsonicus) removal on survival of artificial songbird nests in boreal forest fragments. American Midland Naturalist 147:72-79.

2. BELLES-ISLES, J.-C., and J. PICMAN. 1986. House Wren nest destroying behavior. Condor 88:190-193.

3. GARDALI, T., and G. BALLARD. 2000. Warbling Vireo (Vireo gilvus). In: Poole, A. and F. Gill (eds.). The Birds of North America, No. 551. The Birds of North America, Inc., Philadelphia, PA.

4. LARIVIÈRE, S. 1999. Reasons why predators cannot be inferred from nest remains. Condor 101:718721 .

5. LOWTHER, P. E., C. CELADA, N. K. KLEIN, C. C. RIMMER, and D. A. SPECTOR. 1999. Yellow Warbler (Dendroica petechia). In: Poole, A. and F. Gill (eds.). The Birds of North America, No. 454. The Birds of North America, Inc., Philadelphia, PA.

6. NERO, R. W. 1993. Another red squirrel bird-kill. Blue Jay 51:217-218.

7. PETTINGILL, O. S., JR. 1976. Observed acts of predation on birds in northern lower Michigan. Living Bird 15:33-41.

8. SEALY, S. G. 1992. Removal of Yellow Warbler eggs in association with cowbird parasitism. Condor 94:40-54.

9. SEALY, S. G. 1994. Observed acts of egg destruction, egg removal, and predation on nests of passerine birds at Delta Marsh, Manitoba. Canadian Field-Naturalist 108:41-51.

10. STEELE, M. A. 1998. Tamiasciurus hudsonicus. Mammalian Species 586:1-9.

11. TEWKSBURY, J. J., S. J. HEJL, and T. E. MARTIN. 1998. Breeding productivity does not decline with increasing fragmentation in a western landscape. Ecology 79:2890-2903. 